\title{
Utilizing Modern Systems in Online Replacement of Pipelines in Crisis Management and Passive Defense of Vital Lifelines
}

\author{
Kaveh Ostad-Ali-Askari ${ }^{1 *}$, Saeid Eslamian ${ }^{2}$, Reza Ershadi-Farsani ${ }^{3}$, Theodore C. Crusberg ${ }^{4}$, \\ Vijay P. Singh ${ }^{5}$, Nicolas R. Dalezios ${ }^{6}$ \\ $1^{*}$ Department of Civil Engineering, Isfahan (Khorasgan) Branch, Islamic Azad University, Isfahan, Iran. \\ ${ }^{2}$ Department of Water Engineering, Isfahan University of Technology, Isfahan, Iran. \\ ${ }^{3}$ Department of Civil Engineering, Najafabad Branch, Islamic Azad University, Najafabad, Iran. \\ ${ }^{4}$ Department of Biology and Biotechnology, Worcester Polytechnic Institute, Worcester, MA 01609-2280, U.S.A. \\ ${ }^{5}$ Department of Biological and Agricultural Engineering \& Zachry Department of Civil Engineering, Texas A \\ and M University, 321 Scoates Hall, 2117 TAMU, College Station, Texas 77843-2117, U.S.A. \\ ${ }^{6}$ Laboratory of Hydrology, Department of Civil Engineering, University of Thessaly, Volos, Greece \& \\ Department of Natural Resources Development and Agricultural Engineering, Agricultural University of \\ Athens, Athens, Greece.
}

*Corresponding Author: Dr. Kaveh Ostad-Ali-Askari, Department of Civil Engineering, Isfahan (Khorasgan) Branch, Islamic Azad University, Isfahan, Iran.

\begin{abstract}
Every once in a while in sidewalks and streets of our country's cities and even rural areas, we are witnessing various drillings from different city organizations and institutes including municipalities, electricity companies, and etc. These drillings that are being done for different reasons such as creating pipeline networks for transferring water, sewage, natural gas and even transfer and distribution of petroleum fuels including raw oil and in some cases for cable lines of electricity and telecommunications, it might be for the first time and in fact for constructing and installing new pipelines and cable lines or that due to defects and damages to existing underground pipes and cables, it would be necessary to drill, excavate and exchange or repair networks.
\end{abstract}

Keywords: Crisis management, passive defense, vital lifelines

\section{INTRODUCTION}

Since our country is located on the earthquake line, every once in a while, we witness horrifying events in different parts of the country, which leads to death and injury of a large number of our compatriots and major damages to our country's economy. Similar more severe events in other countries, especially in advance countries, should bring us to this belief that earthquake should not be an unappeasable phenomenon and its related losses and damages should not be considered as unchangeable; yet we should become determined and like other countries, we should start to deal with it in a serious manner. Through the valuable progresses in the science and technology, important steps have been taken in the path of innovation, production, constructiveness and optimization of economic conditions in our country has fortunately provided the required ground for a serious act in this matter and maybe it leaves no more excuses for accepting continuous damages of this matter.

\section{ITEMS OF INVESTIGATION}

Generally, the exchange or repair of pipeline networks is done for various reasons. Inappropriate, design and execution of pipe networks or cable lines, especially failure to be futuristic and to consider the issue of population growth rate that utilizes these facilities, in designing these networks, leads to the inability of these networks' capacities to meet the demand of the entering population in city communities. Also, the lack of geotechnical and scientific, technical and engineering tectonic studies for understanding the quantity, material, density and other features of soil layers in order to 
understand the destructive effects of soil and the waste materials that exist in soil (which all these factors finally lead to the destruction of pipelines and cable lines).

Inappropriate execution of trenches, insufficient density of subbase soil of the drilled canals for solidifying pipelines, and inappropriate and non-technical infrastructure (which this matter both as far as practicality (inappropriate pipe slope and problem in the process of directing the substances inside the pipes, especially sewages) and as far as structure (entrance of additional load and pressure on pipes due to reasons such as shallowness underneath in which state that under them is hollow, in fact they play the role of a small bridge so that a closed space is created for transfer of substances) will cause major problems.

The poor quality material pipes and cables that are used in building underground transfer and distribution networks, and consequently the need to repair or exchange them after a short period of time, small volumes (transfer capacity) of pipes for supplying the need of all residents, and consequently the need to increase the size of these pipes, every once in a while, lack of sufficient resistance of pipes for tolerating the pressure of upper layers of soil that is covered with and as a result, breakage and explosion of pipes and cut-off in the process of transfer and on the other hand, inflicting further costs of drilling, repair and exchange of damaged pipes are among these problems. In this state, it is best to utilize a modern method named Micro tunneling, which will be discussed further in this study.

Adverse effects of soil's environmental conditions, especially frostbites and ice and the continuous melting of the wet soils around the pipes, the offering of pipes and cables made with modern materials and technologies by the pipe market with higher and better efficiencies, and of course less repair and maintenance rates, longer lifetimes and as a result exchange and replacement of old and torn networks with these new systems and etc. are among the most important noteworthy factors regarding the exchange or repair of transfer and distribution pipeline networks for water, natural gas and etc.

However, the main issue starts after the preliminary study plans, executive drilling and excavation operations and execution of trenches. Problems that include major expenses and time consumption by construction and maintenance executing organizations for these networks, the possibility of damages occurring in network's intact parts during drilling and excavation operations for repairing and renovating damaged parts of the network, destruction of asphalted surfaces of streets and sidewalks where these type of pipelines run under (which this issue, in addition to inflicting financial and time costs that is dedicated for repairing and renovating these sidewalks and the network itself, it also causes a unpleasant view of the city and disorients the city's architectural order and façade), disconnection or creation of obstacles in residents' regular paths and public and private vehicles (and consequently, inflicting major expenses for real and legal entities for performing daily errands) and many other problems.

Considering the above-mentioned problems and inconveniences in regards to direct drillings and trench-making for construction or repair of underground pipeline or cable line networks that are considered as the cities' vital lifelines, and on the other hand, given the increasing growth of population and the necessity for more, better and more modern service to residents, especially in the field of underground facilities, utilizing modern methods based on world's latest technologies is an inevitable and necessary matter for city services organizations, institutes and departments.

\section{Proper Solutions}

During the recent years, especially in countries such as England, Germany and many other European countries, significant advancements and transformations has taken place in the field of construction, repair and renovation of transfer and distribution networks for water, sewage, natural gas and electricity, which with the help of European countries this system is also executable in Asian countries such as Thailand. Completely scientific and technical methods that if the necessary execution conditions such as environmental, economical, network characteristics (transfer capacity, path length, ...), region's soil type and etc. are available, they can be considered as a very proper and ideal alternative for replacing direct drilling methods, which require a high volume of soil operations 
(cut and fill) and other financial and time costs. Among the most important modern methods that are called Online Replacement Systems, the following can be mentioned: Pipe Jacking method, Clear Line Expanding method, Micro-Tunneling methods, Pipe Reaming method, Pipe Bursting method and a several other methods. The use of such non-drilling methods dates back to year 1890. It was during this time that for the first time in England, the piping for transferring water and sewage was done without the drilling and excavation operations. Or for example, in the water and sewage transfer system in Bangkok the capital of Thailand with a high population that needs city services on an extensive scale, the Pipe Jacking methods has been used. Since this city is located on the plain of Chao Phraya river that has very soft soil for passing pipes through it with the pressure of hydraulic and pneumatic, is very ideal for using Pipe Jacking method and in fact the city authorities have reached desired results after performing construction and replacement operations for underground transfer and distribution networks. The Pipe Jacking system that has been used in the city of Bangkok, treats about 2.6 million cubic meters of this city's wastewaters that $25 \%$ of it is industrial sewages on a daily basis, and transfers them to septic tanks for its reuse. A major amount of these wastewaters like many other cities in the world including our country are poured into the Phraya river through leading canals. Considering the tectonic status of the region, the location of executive operations and also considering the type of network and the aims for creating it, each of the systems mentionedabove have certain applications. For example, the Bursting Pipe method that is used by the Vermeersporta Burst for replacing not very large pipes with diameters of 8 to 30 centimeters and minimum length of 30 meters. Or that the Clear Line Expandit system that uses a hydraulic system, is specifically designed for replacing gravity pipelines. In most of these systems, only a small amount of drilling is required for grounding the tools and devices. For instance, in methods such as Pipe Bursting in which the force of hydraulic jacks is used for grounding the pipes, after planting the equipment and performing a small amount of excavation until the required depth for laying the pipes is reached, they are respectively placed in the device's hydraulic jaw and with the force entered by the device, pipes are grounded in their permanent desired location. But before this, the frontal side of a drill is sent into the soil and then with the opening of the drill head's teeth, the previous pipe is smashed and sent to the side and new pipes that are usually made of polyethylene are replaced with hydraulic force. In some cases, those involved in the matter are forced to use special material drill heads with high resistance in order to smash steel and cast iron pipes. However, in the case of steel and cast iron pipes it should be mentioned that renovation and repair of these type of pipes using cleaning or repair systems is preferred over fully replacing them. The Pipe Bursting system was invented and used for the first time by the British Natural Gas Company and D.J Ryan Company. These methods in some countries is also known as the Pipe Cracking method. In addition to the above-mentioned companies, the Clampburster, MC Elroys Bulet, Consplit, EESIG Germany and Tracto Technik companies are among the major companies that offer the facilities and services for the Bursting method in which the previous pipe is smashed and busted and the new pipe is replaced, in a fully professional and scientific manner. In regards to Tracto Technik Company it should be mentioned that this company uses the two methods of Dynamic Cracking and Pipe Bursting for repairing and renovating water and natural gas piping networks; which these methods are suitable for pipes made of concrete, plastic and concrete asbestos. This company offers the replacement of pipes with diameters up to 1.2 meters. However, ESSIG Germany company uses pneumatic or air machines for exchanging and laying concrete, clay and concrete asbestos pipes up to $500 \mathrm{~mm}$ diameters. This company is experienced in laying pipes with length of 120 meters through one stage of piping executive operations without drilling and excavating trenches. In modern pipe laying methods, for driving the new pipe ahead and grounding it in place, either a system consisted of a hydraulic jack, belt and drill head is used or a hydraulic jack is used by itself; which the combination system that includes a belt and drill head is more suitable, because refraction is minimized from the path of the bursting head and finally the new pipe, and grounding or replacing the pipes is done a very appropriate manner. Using hydraulic jacks by themselves requires its specific circumstances. Among those is that the soil should not be very hard and tough like clay and sandy soils and on the other hand in this method, thpresse force of the hydraulic jack is the main and determinant factor. 


\section{CONCLusion}

Some of the most important advantages of such systems that can be mentioned are as follows:

No need for drilling and trenching in different regions and creating problems and damages to other underground facilities, high speed in pipe and cable installation operations or replacement of those existing in water, sewage, natural gas, electricity and telephone transfer and distribution networks, shorter timeline for executive operations, no disruptions in city and intercity transportation lines and also sidewalks and streets, preventing the destruction and damaging of asphalted street surfaces, buildings and structures that the transfer and distribution networks pass under.

\section{REFERENCE}

[1] Ostad-Ali-Askari, K., Shayannejad, M. 2015, Study of sensitivity of Autumnal wheat to under irrigation in Shahrekord, Shahrekord City, Iran. International Journal of Agriculture and Crop Sciences, 8 (4), 602-605.

[2] Shayannejad, M., Akbari, N., Ostad-Ali-Askari, K. 2015, Study of modifications of the river physical specifications on muskingum coefficients, through employment of genetic algorithm. International Journal of Development Research, 5(3), 3782-3785.

[3] Ostad-Ali-Askari, K., Shayannejad, M. 2015, The Reviews of Einstein's Equation of Logarithmic Distribution Platform and the Process of Changes in the Speed Range of the Karkheh River, Khuzestan province, Iran. International Journal of Development Research, 5(3), 3786-3790.

[4] Ostad-Ali-Askari, K., Shayannejad, M., Ghorbanizadee-Kharazi, H. 2015, Assessment of artificial neural network performance and exponential regression in prediction of effective rainfall, International Journal of Development Research, 5(3), 3791-3794.

[5] Shayannejad, M. Akbari, N. and Ostad-Ali-Askari, K. 2015, Determination of the nonlinear Muskingum model coefficients using genetic algorithm and numerical solution of the continuity. Int. J. of Science: Basic and Applied Research, 21(1), 1-14.

[6] Ostad-Ali-Askari, K., Shayannejad, M. 2015, the Study of Mixture Design for Foam Bitumen and the Polymeric and Oil Materials Function in Loose Soils Consolidation. Journal of Civil Engineering Research, 5(2), 39-44. DOI: 10.5923/j.jce.20150502.04

[7] Sayedipour, M., Ostad-Ali-Askari, K., Shayannejad, M. 2015, Recovery of Runoff of the Sewage Refinery, a Factor for Balancing the Isfahan-Borkhar Plain Water Table in Drought Crisis Situation in Isfahan Province-Iran. American Journal of Environmental Engineering, 5(2): 43-46. DOI: 10.5923/j.ajee.20150502.02

[8] Ostad-Ali-Askari, K., Shayannejad, M. 2015, Developing an Optimal Design Model of Furrow Irrigation Based on the Minimum Cost and Maximum Irrigation Efficiency. International Bulletin of Water Resources \& Development, 3(2), 18-23.

[9] Ostad-Ali-Askari K. Groundwater. Horoufchin publisher, First Edition, 2015. ISBN: 978-600-7419-33-5. Isfahan, Iran.

[10] Shayannejad M, Ostad-Ali-Askari K. Modeling of solute movement in groundwater. Kankash publisher. First edition, 2015. ISBN: 978-600-136-256-9. Isfahan, Iran.

Citation: Kaveh Ostad-Ali-Askariet.al., "Utilizing Modern Systems in Online Replacement of Pipelines in Crisis Management and Passive Defense of Vital Lifelines", International Journal of Constructive Research in Civil Engineering, 4(2), pp. 27-30. DOI: http://dx. doi.org/10.20431/2454-8693.0402005

Copyright: $\odot 2018$ Kaveh Ostad-Ali-Askari et.al., This is an open-access article distributed under the terms of the Creative Commons Attribution License, which permits unrestricted use, distribution, and reproduction in any medium, provided the original author and source are credited. 